\title{
Effect of Ketogenic Mediterranean diet with phytoextracts and low carbohydrates/high- protein meals on weight, cardiovascular risk factors, body composition and diet compliance in Italian council employees
}

\author{
Antonio Paoli ${ }^{*}$, Lorenzo Cenci $^{2}$ and Keith A Grimaldi ${ }^{3}$
}

\begin{abstract}
Background: There has been increased interest in recent years in very low carbohydrate ketogenic diets (VLCKD) that, even though they are much discussed and often opposed, have undoubtedly been shown to be effective, at least in the short to medium term, as a tool to tackle obesity, hyperlipidemia and some cardiovascular risk factors. For this reason the ketogenic diet represents an interesting option but unfortunately suffers from a low compliance. The aim of this pilot study is to ascertain the safety and effects of a modified ketogenic diet that utilizes ingredients which are low in carbohydrates but are formulated to simulate its aspect and taste and also contain phytoextracts to add beneficial effects of important vegetable components.
\end{abstract}

Methods: The study group consisted of 106 Rome council employees with a body mass index of $\geq 25$, age between 18 and 65 years (19 male and 87 female; mean age $48.49 \pm 10.3$ ). We investigated the effects of a modified ketogenic diet based on green vegetables, olive oil, fish and meat plus dishes composed of high quality protein and virtually zero carbohydrate but which mimic their taste, with the addition of some herbal extracts (KEMEPHY ketogenic Mediterranean with phytoextracts). Calories in the diet were unlimited. Measurements were taken before and after 6 weeks of diet.

Results: There were no significant changes in BUN, ALT, AST, GGT and blood creatinine. We detected a significant ( $p<0.0001)$ reduction in BMl $\left(31.45 \mathrm{Kg} / \mathrm{m}^{2}\right.$ to $\left.29.01 \mathrm{Kg} / \mathrm{m}^{2}\right)$, body weight $(86.15 \mathrm{~kg}$ to $79.43 \mathrm{Kg}$ ), percentage of fat mass $(41.24 \%$ to $34.99 \%)$, waist circumference $(106.56 \mathrm{~cm}$ to $97.10 \mathrm{~cm})$, total cholesterol $(204 \mathrm{mg} / \mathrm{dl}$ to $181 \mathrm{mg} / \mathrm{dl})$, LDLc $(150 \mathrm{mg} / \mathrm{dl}$ to $136 \mathrm{mg} / \mathrm{dl})$, triglycerides $(119 \mathrm{mg} / \mathrm{dl}$ to $93 \mathrm{mg} / \mathrm{dl})$ and blood glucose $(96 \mathrm{mg} / \mathrm{dl}$ to $91 \mathrm{mg} / \mathrm{dl})$. There was a significant $(p<0.0001)$ increase in HDLc $(46 \mathrm{mg} / \mathrm{dl}$ to $52 \mathrm{mg} / \mathrm{dl})$.

Conclusions: The KEMEPHY diet lead to weight reduction, improvements in cardiovascular risk markers, reduction in waist circumference and showed good compliance.

\section{Background}

Obesity has become a health emergency in Western countries $[1,2]$. As is well known, obesity and in particular abdominal obesity is one of the principle risk factors for cardiovascular disease and along with dyslipidemia,

\footnotetext{
* Correspondence: antonio.paoli@unipd.it

'Department of Human Anatomy and Physiology, University of Padova, Padova, Italy

Full list of author information is available at the end of the article
}

hypertension and diabetes contributes to the metabolic syndrome [3]. Even though weight loss is a desired goal for most overweight individuals, and its health benefits have been clearly determined [4,5], there are still no definitive data on what dietary protocols are most effective in both the short and long term [6] or even what is the correct nutritional approach in general [7].

The most commonly accepted dietary strategy is based on relatively high levels of carbohydrates and low fat
C Biomed Central

() 2011 Paoli et al; licensee BioMed Central Ltd. This is an Open Access article distributed under the terms of the Creative Commons Attribution License (http://creativecommons.org/licenses/by/2.0), which permits unrestricted use, distribution, and reproduction in any medium, provided the original work is properly cited. 
content but according to some studies these low fat diets yield only modest weight loss and suffer from low long-term compliance [8]. In fact adherence of overweight/obese individuals to high carbohydrate/low fat nutrition is often a problem because the majority have been shown to have dietary preferences for foods with a rich fat content. Furthermore rather than consume complex carbohydrates there is a tendency to prefer highly processed food containing simple sugars [9-11] such that a low fat diet can actually encourage the consumption of sugars and refined carbohydrates that can worsen weight problems and also facilitate dyslipidemia especially in insulin resistance individuals $[12,13]$. As a consequence of the relative inefficacy of these types of diet there has been increased interest in recent years in very low carbohydrate ketogenic diets (VLCKD) [14] that, have undoubtedly been shown to be effective, at least in the short to medium term, as a tool to tackle obesity, hyperlipidemia and some cardiovascular risk factors [15-18]. The Mediterranean diet is often proposed as the healthy standard but many of the advantages associated with it can actually be linked to life style and the true original Mediterranean diet did not contemplate the current high levels of refined carbohydrates on which the typical Italian diet is based $[19,20]$. For this reason the standard ketogenic diet is not associated with high compliance in populations, like the Italian, that are used to carbohydrate based diets. The objective of the present study, which was devised as a case pilot trial, is to assess the safety, compliance and effects of a "Mediterranean style" ketogenic diet that utilizes very low carbohydrate ingredients formulated to simulate the aspect and taste of common carbohydrate rich foods (e.g. pasta) and which contain phytoextracts intended to add beneficial effects of important vegetable components. The aim of using herbal extracts during the diet period was to reduce some commonly reported light side effects of ketogenic diets. The parameters measured include blood biomarkers, body composition, weight loss and compliance in a cohort of council employees in Rome, Italy.

\section{Methods}

\section{Subjects}

The pilot study group consisted of 106 Rome council employees (19 males and 87 female; mean age 48, $49 \pm$ $10,33)$. Inclusion criteria were: $\mathrm{BMI} \geq 25$, age $>18$ years and $<65$ years, currently on a carbohydrate rich diet (> 50\% energy), [21] desire to lose weight and health status suitable for a modified ketogenic diet $\left(\right.$ Tisanoreica ${ }^{\circledR}$ ) [22] i.e. normal renal function, not pregnant or lactating. After the start of the experimental protocol the subjects who began new exercise programs or pharmaceutical treatments would be excluded. A small rise in transaminase was not considered a condition for exclusion since mild alterations in GOT and GPT values are common in obese individuals. Subjects eligible for the study were invited to the IPA clinic (Istituto di Previdenza ed Assistenza - health services for public sector employees) to attend an orientation session. At the first visit it was explained that during the first three weeks it was necessary to almost totally exclude carbohydrates and a detailed menu containing permitted and non-permitted foods was provided to each participant, along with the components of the ketogenic Mediterranean with phytoextracts (KEMEPHY) diet described below. Anthropometric measures were performed and blood samples were taken from the subjects two-three days before and after they began the diet. Subjects received no monetary compensation for their participation and signed a voluntary consent form before initiating the diet. The ethical and clinical review committee of IPA and the European Nutrition Society approved the study protocol, informed consent form and information material provided to subjects.

\section{Diet}

The KEMEPHY (ketogenic Mediterranean with phytoextracts) diet protocol was ketogenic during the first 3 weeks with approximately $34 \mathrm{~g}$ of $\mathrm{CHO}$ daily, using low carbohydrate high-protein meals and herbal teas [22] (Tisanoreica ${ }^{\circledR}$ by Gianluca Mech SpA, Orgiano VI) (Table 1 and 2).

The permitted foods were: cooked or raw green vegetables (200 g/meal), meat, fish and eggs (2 times/day), olive oil $40 \mathrm{~g} /$ day. Integration with a dish $\left(\mathrm{PAT}^{\circledR}\right.$ i.e. porzione alimentare tisanoreica $=$ tisanoreica nutritional portion) composed of high quality proteins (equivalent to 18 grams) and virtually zero carbohydrate (but that mimic their taste) was provided for every meal, for a maximum of four PATs per day. During the last three weeks complex carbohydrates were introduced (50-80 g/ day), cheese (60 g/day), PAT was reduced from four to two, while the other indications remained unchanged. The distribution of nutrients (proteins, carbohydrates and fats) in terms of percentage of total caloric intake was $36 \%, 12 \%$ and $52 \%$, respectively (weeks 1 to 3 ) and $31 \%, 25 \%$ and $44 \%$ (weeks 4 to 6). During the 6 weeks, the patients in the study group consumed $20 \mathrm{ml}$ of extract A, $20 \mathrm{ml}$ of extract $\mathrm{B}$ and $50 \mathrm{ml}$ of extract C. During the first two weeks, before breakfast and lunch, they also consumed $40 \mathrm{ml}$ of extract D (Tables 2 and 3).

\section{Supplements}

Subjects also took a daily ( 1 caplet each morning) multivitamin supplement [23] (containing Magnesium19 mg, Calcium $16 \mathrm{mg}$, Phosphorus $8 \mathrm{mg}$, Zinc $4.5 \mathrm{mg}$, Iron $4.62 \mathrm{mg}$, Manganese $1 \mathrm{mg}$, Potassium $0.5 \mathrm{mg}$, Copper 
Table 1 diet composition in KEMEPHY (ketogenic Mediterranean with phytoextracts) diet.

\begin{tabular}{ccc}
\hline & KEMEPHY Week 1-3 & KEMEPHY Week 4-6 \\
\hline Energy Kcal & $1098 \pm \mathbf{2 1 . 3}$ & $1186 \pm 107$ \\
\hline $\begin{array}{c}\text { Protein, g/day } \\
\text { (\% daily Energy) }\end{array}$ & $99(36)$ & 91 (31) \\
\hline $\begin{array}{c}\text { Fat, g/day } \\
\text { (\% daily Energy) }\end{array}$ & $34(12)$ & $74(25)$ \\
\hline Mean Kcal/die of the two phases of KEMEPHY & $63(52)$ & $58(44)$ \\
\hline
\end{tabular}

Kcal values are expressed in mean per day and SD. Other values are expressed in mean per day.

$0.4 \mathrm{mg}$, Chromium $28.55 \mu \mathrm{g}$, Selenium $4 \mu \mathrm{g}$, Niacin 10 $\mathrm{mg}$, Beta carotene $1.8 \mathrm{mg}$, Folic Acid $66 \mu \mathrm{g}$, Biotin 30 $\mu \mathrm{g}$, Vitamin C $19.8 \mathrm{mg}$, Vitamin E $3.3 \mathrm{mg}$, Pantothenic Acid $1.98 \mathrm{mg}$, Vitamin B6 $0.66 \mathrm{mg}$, Vitamin B2 $0.53 \mathrm{mg}$, Vitamin B1 0.426 mg, Vitamin D3 $1.65 \mu \mathrm{g}$, Vitamin B12 $0.33 \mu \mathrm{g}$ (Multivitaminico Balestra e Mech, Gianluca Mech SpA, Orgiano VI).

\section{Measurements}

Subjects were weighed at the same time of day at the start and after 6 weeks of the diet, using the same weighing scales (Digital Scale Joycare ${ }^{\circledR}$ Jc431). Fasting venous blood samples were collected at weeks 0 and 6 for total cholesterol (CHOLt), triacyglicerol (TG) highdensity lipoprotein cholesterol (HDLc), low-density lipoprotein cholesterol (LDLc), glucose, blood urea nitrogen (BUN), uricemia, VES, creatinine, ALT, AST, GGT. Blood was collected in EDTA treated vacutainer tubes. To avoid interassay variation all blood samples were stored at $-80^{\circ}$ and analysed together at the end of the study. A separate sample of blood was clotted and serum analyzed for total cholesterol and triacylglycerols by photometric assay with an intra-assay and interassay CV values of $2 \%$ and $4 \%$, respectively.

HDL cholesterol was determined using a homogenous enzyme immunoassay. The intra-assay and interassay $\mathrm{CV}$ values were both $<4 \%$. Plasma glucose was determined colorimetrically using glucose oxidase methodology. Plasma urea nitrogen were measured using an enzymatic (urease), colorimetric method. Creatinine was measured colorimetrically using the picric acid assay, and uric acid was determined using a modified Trinder peroxide assay. LDLc fraction was calculated from Friedewald's formula: LDLc $=\mathrm{TC}$ HDLc - (TG/5) [24]. Body composition was assessed using bioelectrical impedance analysis (BIA Akern Bioresearch, Pontassieve, FI, Italy) which is a non-invasive and portable method for the estimation of fluid compartments, fat and fat-free mass in healthy subjects. Bioelectrical impedance analysis was chosen for the analysis of body composition due to its reliability, safety, convenience and non-invasiveness making it optimal for the routine monitoring of body composition during the ketogenic diet $[25,26]$. The experimental design is showed in Figure 1.

\section{Statistical analysis}

We tested the normality and the assumption of homoscedasticity of all parameters at the start of the trial using the Kolmogorov-Sminorv and Shapiro-Wilk tests. To study changes over time and the effects of gender, we added an appropriate interaction analysis. As there were no significant gender interactions, the data of each group were pooled and analyzed together. A Student's t test was used to compare parameters before and after 6 weeks of the KEMEPHY diet using Statistica Software, ver. 8.0 (Tulsa, USA) and the software package GraphPad Prism version 4.00 for Windows, GraphPad

Table 2 Plant extracts used in KEMEPHY (ketogenic Mediterranean with phytoextracts) diet

\begin{tabular}{cccc} 
Plant extracts & $\begin{array}{c}\text { Week } \\
\mathbf{1 - 3}\end{array}$ & $\begin{array}{c}\text { Week } \\
\mathbf{4 - 6}\end{array}$ & Composition \\
\hline $\begin{array}{c}\text { Extracts A, ml/ } \\
\text { day }\end{array}$ & 20 & 20 & $\begin{array}{r}\text { Durvillea antarctica, black radish, mint, liquorice, artichoke, horsetail, burdock, dandelion, rhubarb, gentian, } \\
\text { lemon balm, chinaroot, juniper, spear grass, elder, fucus, anise, parsley, bearberry, horehound }\end{array}$ \\
\hline $\begin{array}{c}\text { Extracts B, ml/ } \\
\text { day }\end{array}$ & 20 & 20 & Serenoa, Red clover, Chervil, Bean, Elder, Dandelion, Uncaria, Equisetum, Horehound, Rosemary \\
\hline $\begin{array}{c}\text { Extracts C, ml/ } \\
\text { day }\end{array}$ & 50 & 50 & Horsetail, asparagus, birch, cypress, couch grass, corn, dandelion, grape, fennel, elder, rosehip, anise \\
\hline $\begin{array}{c}\text { Extracts D, ml/ } \\
\text { day }\end{array}$ & 40 & 0 & Eleuthero, eurycoma longifolia, ginseng, corn, miura puama, grape, guaranà, arabic coffee, ginger \\
$\begin{array}{c}\text { (only weeks } 1 \\
\text { and 2) }\end{array}$ & & \\
\hline
\end{tabular}


Table 3 Main actives ingredients of used phytoextracts, their reported beneficial effects and related references

\begin{tabular}{|c|c|c|c|}
\hline Extract & Main Active ingredients & Reported beneficial effects & Refs \\
\hline A & $\begin{array}{l}\text { Mint } \\
\text { black radish } \\
\text { burdock }\end{array}$ & $\begin{array}{l}\text { - indigestion } \\
\text { - antioxidant } \\
\text { - choleretic, increases bile secretion helping digestion }\end{array}$ & $\begin{array}{l}{[69]} \\
{[70]}\end{array}$ \\
\hline \multirow[t]{2}{*}{ B } & $\begin{array}{l}\text { Serenoa Repens (saw } \\
\text { palmetto) }\end{array}$ & hormonal regulating effects & [71] \\
\hline & White bean & alpha-amylase inhibitory properties and has been reported to aid weight loss and glycemic control & $\begin{array}{l}{[72]} \\
{[73]}\end{array}$ \\
\hline \multirow[t]{2}{*}{ C } & Equisetum & $\begin{array}{l}\text { Antioxidant } \\
\text { diuretic } \\
\text { glycemic control }\end{array}$ & $\begin{array}{l}{[74]} \\
{[75]}\end{array}$ \\
\hline & $\begin{array}{l}\text { Dandelion (Taraxacum } \\
\text { officinale }\end{array}$ & diuretic & [76] \\
\hline D & $\begin{array}{l}\text { Ginseng } \\
\text { Miura Puama } \\
\text { Guaranà }\end{array}$ & $\begin{array}{l}\text { Ameliorate the commonly reported symptoms of weakness and tiredness during the } 1^{\text {st }} \text { phase of } \\
\text { ketosis ( } 1 / 2 \text { weeks) }\end{array}$ & $\begin{array}{l}{[77]} \\
{[78]} \\
{[79]}\end{array}$ \\
\hline
\end{tabular}

Software, San Diego California USA. All data are expressed as mean \pm standard deviation.

\section{Results}

Of the 106 persons recruited 87 completed the study (83, 6\% compliance). Of the 19 subjects that withdrew 4 were for family/personal reasons, 8 subjects were lost to follow up and only 7 withdrew due to inadequate compliance to the diet protocol. Adjusted for causes of withdrawal only 7 of 104 were not able to follow the KEMEPHY diet for an adjusted compliance of $93.4 \%$

Blood analysis did not reveal significant modification in ALT, AST, GGT and bilirubin values, nor were there significant variations in creatinine, uric acid, nitrogen and electrolytes (NA, K, Cl, Ca, Mg). There were significant changes in lipid profiles with reductions in triglycerides, total cholesterol and LDL along with a rise in HDL levels which all reached significance - see Table 4 and 5 .

\section{Blood sample \\ Anthropometric/body composition measurements}

\section{Blood sample \\ Anthropometric/body composition measurements}
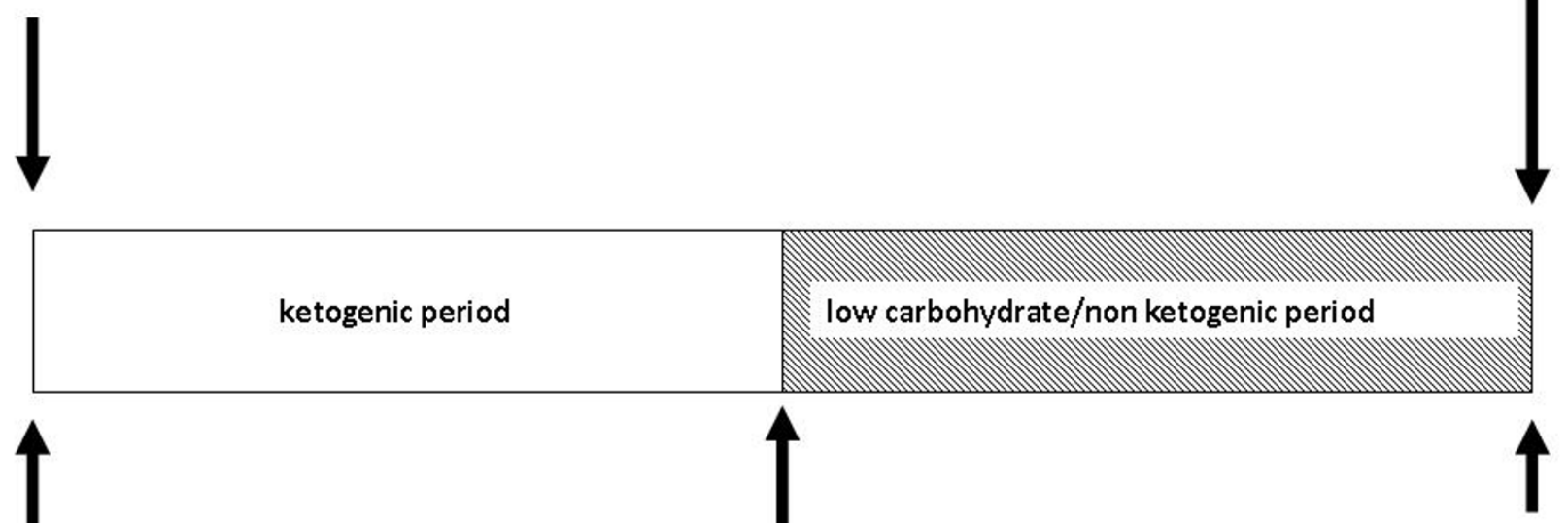

$3^{\circ}$ visit: Diet recall and control

\section{$1^{\circ}$ visit: Diet protocol explaining}

$2^{\circ}$ visit: Diet recall and control

Figure 1 Experimental design. 
Table 4 Blood biomarker, anthropometric and body composition values, separated for male and female, before and after 6 weeks KEMEPHY diet. Values are expressed in mean and SD.

\begin{tabular}{|c|c|c|c|c|}
\hline & Pre diet female & Post diet female & $\begin{array}{l}\text { Pre diet } \\
\text { male }\end{array}$ & $\begin{array}{l}\text { Post diet } \\
\text { male }\end{array}$ \\
\hline BUN (mg/dl) & $33.4 \pm 9.5$ & $33.2 \pm 8.7$ & $35.2 \pm 6.0$ & $33.8 \pm 7.0$ \\
\hline Uric acid (mg/dl) & $5.0 \pm 1.3$ & $5 \pm 1.2$ & $4.8 \pm 1.3$ & $5.0 \pm 1.3$ \\
\hline VES (mm/hour) & $14 \pm 7.3$ & $12.7 \pm 7.6$ & $16 \pm 7.3$ & $14.4 \pm 6.3$ \\
\hline Creatinine (mg/dL) & $0.84 \pm 0.15$ & $0.77 \pm 0.11$ & $0.83 \pm 0.2$ & $0.85 \pm 0.2$ \\
\hline Total Cholesterol (mg/dl) & $206.2 \pm 41.4$ & $182.8 \pm 34.3$ & $199.2 \pm 29.8$ & $176.9 \pm 26.1$ \\
\hline HDLc (mg/dl) & $46.7 \pm 7.2$ & $52.6 \pm 9.5$ & $43.9 \pm 8.5$ & $50.1 \pm 9.1$ \\
\hline LDLc (mg/dl) & $151.8 \pm 28.3$ & $137.1 \pm 24.8$ & $140.9 \pm 32.9$ & $130.4 \pm 25.9$ \\
\hline TG (mg/dl) & $119.9 \pm 60.3$ & $94.2 \pm 41.8$ & $114.1 \pm 61.8$ & $93.9 \pm 46.2$ \\
\hline ALT (U/I) & $20.5 \pm 10.9$ & $17.3 \pm 5.1$ & $18.4 \pm 4.6$ & $19.1 \pm 6.8$ \\
\hline AST (U/I) & $18.5 \pm 5.4$ & $17.1 \pm 4.7$ & $17.8 \pm 3.8$ & $17 \pm 5.1$ \\
\hline GGT (U/I) & $20.5 \pm 10.9$ & $17.3 \pm 5.1$ & $21.5 \pm 11.7$ & $15.4 \pm 4.1$ \\
\hline Glucose (mg/dl) & $95.7 \pm 12.5$ & $90.5 \pm 9.8$ & $95.9 \pm 11.2$ & $90.6 \pm 8$ \\
\hline Weight Kg & $82.6 \pm 12.7$ & $76.3 \pm 12.1$ & $102.4 \pm 22.2$ & $93.4 \pm 21$ \\
\hline BMI $\left(\mathrm{Kg} / \mathrm{m}^{2}\right)$ & $31 \pm 4.8$ & $28.7 \pm 4.6$ & $33.6 \pm 6.2$ & $30.6 \pm 5.8$ \\
\hline$\%$ Fat & $42.3 \pm 6,8$ & $36 \pm 6,9$ & $37 \pm 4.3$ & $30.6 \pm 4.1$ \\
\hline Waist circumference cm & $103.5 \pm 14$ & $94,3 \pm 10.3$ & $120.8 \pm 15.1$ & $109.7 \pm 14.1$ \\
\hline Hip circumference $\mathrm{cm}$ & $114.9 \pm 11.6$ & $107.2 \pm 10.5$ & $117.3 \pm 9.9$ & $111.2 \pm 10.4$ \\
\hline
\end{tabular}

Anthropometric and body composition measurements revealed an average weight loss of $6.72 \mathrm{~kg}$ or $7.8 \%$ (pre $86.15 \pm 16.38$ vs post $79.43 \pm 15.31 ; \mathrm{p}<0.0001)$. Fat mass was reduced from $41.24 \pm 6.74$ to $34.99 \pm 6.74$, a fall of $15.1 \%$ ( $p<0.0001$ ). As in previous studies no significant differences were observed in total body water expressed as percent of body weight [22,27]. Waist circumference was reduced by an average of $9.46 \mathrm{~cm}$ from $106.56 \pm 15.38$ to $97.10 \pm 12.69$, a fall of $8.9 \%$ (p <

Table 5 Blood biomarker values (all subjects) before and after the 6 week KEMEPHY diet. Values are expressed in mean and SD.

\begin{tabular}{lccc}
\hline & $\begin{array}{c}\text { Pre KEMEPHY } \\
\text { diet }\end{array}$ & $\begin{array}{c}\text { Post KEMEPHY } \\
\text { diets }\end{array}$ & $\mathbf{p}$ \\
\hline BUN (mg/dl) & $33.8 \pm 8.9$ & $33.4 \pm 8.4$ & n.s. \\
\hline Uric acid (mg/dl) & $4.9 \pm 1.3$ & $5 \pm 1.2$ & n.s. \\
\hline VES (mm/hour) & $14.2 \pm 7.2$ & $12.8 \pm 7.4$ & n.s. \\
\hline Creatinine (mg/dL) & $0.83 \pm 0.16$ & $0.78 \pm 0.13$ & n.s. \\
\hline $\begin{array}{l}\text { Total Cholesterol } \\
\text { (mg/dl) }\end{array}$ & $204.2 \pm 40$ & $181.1 \pm 33.4$ & $P<0.0001$ \\
\hline HDLc (mg/dl) & $46.2 \pm 7.4$ & $52.1 \pm 7.4$ & $P<0.0001$ \\
\hline LDLc (mg/dl) & $149.7 \pm 29.1$ & $135.8 \pm 24.8$ & $P<0.0001$ \\
\hline TG (mg/dl) & $118.6 \pm 59.9$ & $93.8 \pm 42.2$ & $P<0.0001$ \\
\hline ALT (U/l) & $20.7 \pm 9.1$ & $18.2 \pm 6.7$ & n.s. \\
\hline AST (U/l) & $18.4 \pm 5.1$ & $17 \pm 5$ & n.s. \\
\hline GGT (U/l) & $21 \pm 11$ & $17 \pm 5$ & n.s. \\
\hline Glucose (mg/dl) & $96 \pm 12$ & $91 \pm 9$ & $P<0.0001$ \\
\hline
\end{tabular}

0.0001). There were also significant reductions in hip and thigh circumferences of $7.41 \mathrm{~cm}$ (from $115 \pm 11.24$ to $107.78 \pm 10.39 ; \mathrm{p}<0.0001)$ and $3.32 \mathrm{~cm}$ respectively (from $58.65 \pm 5.43$ to $55.32 \pm 4.90$ ). Anthropometric and body composition results are showed in tables 6 .

\section{Discussion}

Many weight loss diet procedures continue to focus on the reduction of fat content and controlled protein intake, however our results appear to demonstrate that the KEMEPHY diet, which is a modification of the VLCKD, is effective not only for weight and fat loss but also leads to improvements in the values of various biomarkers which are associated with increased risk of metabolic and cardiovascular disease. The weight loss effect of VLCKD diets may be caused by several factors:

Table 6 Anthropometric and body composition measures (all subjects) pre and post diet

\begin{tabular}{lccc}
\hline & $\begin{array}{c}\text { Pre KEMEPHY } \\
\text { diet }\end{array}$ & $\begin{array}{c}\text { Post KEMEPHY } \\
\text { diets }\end{array}$ & p \\
\hline BMI $\left(\mathrm{Kg} / \mathbf{m}^{2}\right)$ & $31.5 \pm 5.1$ & $29 . \pm 4.8$ & $\mathrm{P}<0.0001$ \\
\hline Weight $\mathrm{Kg}$ & $86.2 \pm 16.4$ & $79.4 \pm 15.3$ & $\mathrm{P}<0.0001$ \\
\hline$\%$ Fat & $41.2 \pm 6.7$ & $35 \pm 6.7$ & $\mathrm{P}<0.0001$ \\
\hline $\begin{array}{l}\text { Waist } \\
\text { circumference cm }\end{array}$ & $106.6 \pm 15.4$ & $97.1 \pm 12.7$ & $\mathrm{P}<0.0001$ \\
\hline $\begin{array}{l}\text { Hip circumference } \\
\text { cm }\end{array}$ & $115 \pm 11.3$ & $107.8 \pm 10.4$ & $\mathrm{P}<0.0001$ \\
\hline
\end{tabular}


1. Satiety effect of proteins leading to appetite reduction [28-36] in which also ketone bodies may have a role $[37,38]$, although the mechanism is not clear [39];

2. Reduction in lipid synthesis and increased lipolysis mechanisms [40-44];

3. Reduction in at rest respiratory quotient and therefore an increase in fat metabolism for energy use $[22,45]$;

4. Increased metabolic expenditure caused by gluconeogenesis and the thermic effect of proteins [46-51]

The beneficial effects on cardiovascular risk factors involve the reduction of blood triglycerides[17,18,22] and also the reduction of total and LDL cholesterol along with a rise in HDL cholesterol [17,18,22,52-54]. Furthermore the VLCKD can cause modifications in LDL-C particles leading to increased size [53] which may reduce cardiovascular risk since smaller LDL particles have been shown to be more atherogenic [55].

The cholesterol lowering effect of VLCKD is also mediated by the well known facilitating action of insulin on HMGCoA reductase and inhibition of the latter by cholesterol and fats [56]. Insulin then increases the production of endogenous cholesterol while exogenous cholesterol has the opposite effect [56].

The KEMEPHY diet protocol used in this study maintains some advantages of the Mediterranean diet such as the use of olive oil [21] and some vegetables [19] (selected to avoid stimulating insulin production) but at the same time by inducing a physiological ketosis [57] promotes beneficial modifications in cardiovascular risk factors and body composition [22]. The use of the phyoextracts in this study may have contributed to the absence of commonly reported mild effects of ketosis (e. g. weakness, constipation, bad breath, headache). During the first three weeks of the KEMEPHY diet subjects avoided fructose completely and during the second three weeks only a moderate amount of fructose, exclusively from fruit, and therefore together with starch, was permitted. As a matter of fact fructose may stimulate fat biosynthesis via mechanisms which are not yet fully characterised [58], also several studies have reported that excessive concentrations of fructose can induce some or all of the features of metabolic syndrome independently of energy intake. Clinical and epidemiologic data further suggest that excessive fructose intake can contribute to the causes of metabolic syndrome [59].

Adjusted compliance in this study was $93.4 \%$ which is higher than reported compliances of standard VLCK diets (in the $20 \%$ to $58 \%$ range). [22,60,61]. It is tempting to speculate that the inclusion of "carbohydrate-like" formulated foods is one of the reasons for high compliance - however this, along with the potential benefits of the phytoextracts, requires further verification in a future study with a matched control group.

\section{Safety considerations}

If we assimilate de facto, which is not always correct, ketogenic diets with high protein diets then the risks proposed by critics of this type of dietary approach are essentially those of possible kidney damage due to high levels of nitrogen excretion during protein metabolism which can cause an increase in glomerular pressure and hyper-filtration [27]. There is not wide agreement between studies however, some infer the possibility of renal damage from animal studies $[62,63]$ while others, looking at both animal models and human studies propose that even high levels of protein in the diet do not damage renal function $[64,65]$. In subjects with intact renal function higher dietary protein levels caused some functional and morphological adaptations without negative effects [66]. Also it should be underlined that ketogenic diets are only relatively high in protein $[49,67]$ and that some recent studies have demonstrated that VLCKD can even cause a regression of diabetic nephropathy in mice [68]. With regard to possible acidosis during VLCKD since the concentration of ketone bodies never rises above $8 \mathrm{mmol} / \mathrm{l}[40,42]$ this risk is virtually inexistent in subjects with healthy insulin function.

\section{Conclusions}

Some limitations to this study include the lack of a matched control group and the short trial period. There are though many studies that demonstrate that VLCK diets are more effective than low fat or standard Mediterranean diets, at least over the short term [21], and the main aims of the present initial study were to assess safety aspects, acceptance \& palatability and weight loss \& biomarker changes. We are able to conclude that at least in the short term it was able to lead to positive changes including the reduction of fasting blood glucose, improvements in lipid profiles, significant and rapid weight and fat loss with the preservation of lean mass. We also note a high level of compliance, whether this was due to specific unique features of the present diet requires confirmation in a future matched control trial.

\section{Abbreviations}

KEMEPHY: ketogenic Mediterranean with phytoextracts; VLCKD: very low carbohydrate ketogenic diet; high-density lipoprotein cholesterol; LDLc: lowdensity lipoprotein cholesterol; TG: Triglycerides; GLU: Glucose; BUN: Blood Urea Nitrogen; UA: Uric acid; ALT: Alanine aminotransferase; AST: Aspartate Aminotransferase; GGT Gamma-glutamyl transpeptidase; Cr: Creatinine.

\section{Acknowledgements}

The authors thank the men and women who participated in this investigation. 


\section{Author details}

'Department of Human Anatomy and Physiology, University of Padova, Padova, Italy. ${ }^{2}$ Nutrition and Dietetic Service, San Bortolo Hospital, Vicenza, Italy. ${ }^{3}$ Biomedical Engineering Laboratory, Institute of Communication and Computer Systems, National Technical University of Athens, Athens, Greece.

\section{Authors' contributions}

AP was the main researcher and was responsible for study design, statistical analysis and interpretation of data and draft of manuscript. conceived the study, participated in its design, drafted the manuscript and performed the statistical analysis. LC was responsible for study design and acquisition of data. KG was was responsible for analysis and interpretation of data and helped to draft the manuscript. All authors read and approved the final manuscript.

\section{Competing interests}

This work was partially funded by Gianluca Mech SpA, Orgiano (VI), Italy. AP and $L C$ research activity is funded by dept. of Human Anatomy and Physiology, University of Padova; KG research activity is funded by the Biomedical Engineering Laboratory, Institute of Communication and Computer Systems, National Technical University of Athens, Athens, Greece. LC is scientific consultant for Gianluca Mech SpA, Orgiano (VI), Italy. Investigators conducted the study in its entirety and maintained exclusive control of all data and analyses. The funding source had no involvement in any part of the recruitment of participants, study intervention, data collection, data analyses, interpretation of the data, or preparation or review of this manuscript.

Received: 13 July 2011 Accepted: 12 October 2011

Published: 12 October 2011

\section{References}

1. Finkelstein EA, Ruhm CJ, Kosa KM: Economic causes and consequences of obesity. Annu Rev Public Health 2005, 26:239-257.

2. Olshansky SJ, Passaro DJ, Hershow RC, Layden J, Carnes BA, Brody J, Hayflick L, Butler RN, Allison DB, Ludwig DS: A potential decline in life expectancy in the United States in the 21st century. N Engl J Med 2005, 352:1138-1145.

3. Koh-Banerjee P, Wang Y, Hu FB, Spiegelman D, Willett WC, Rimm EB: Changes in body weight and body fat distribution as risk factors for clinical diabetes in US men. Am J Epidemiol 2004, 159:1150-1159.

4. Appel LJ, Champagne CM, Harsha DW, Cooper LS, Obarzanek E, Elmer PJ, Stevens VJ, Vollmer WM, Lin PH, Svetkey LP, Stedman SW, Young DR, Writing Group of the PREMIER Collaborative Research Group: Effects of comprehensive lifestyle modification on blood pressure control: main results of the PREMIER clinical trial. JAMA 2003, 289:2083-2093.

5. Knowler WC, Barrett-Connor E, Fowler SE, Hamman RF, Lachin JM, Walker EA, Nathan DM, Diabetes Prevention Program Research Group: Reduction in the incidence of type 2 diabetes with lifestyle intervention or metformin. N Engl J Med 2002, 346:393-403.

6. Nordmann AJ, Nordmann A, Briel M, Keller U, Yancy WS Jr, Brehm BJ, Bucher HC: Effects of low-carbohydrate vs low-fat diets on weight loss and cardiovascular risk factors: a meta-analysis of randomized controlled trials. Arch Intern Med 2006, 166:285-293.

7. Chahoud G, Aude YW, Mehta JL: Dietary recommendations in the prevention and treatment of coronary heart disease: do we have the ideal diet yet? Am J Cardiol 2004, 94:1260-1267.

8. Brehm BJ, Seeley RJ, Daniels SR, D'Alessio DA: A randomized trial comparing a very low carbohydrate diet and a calorie-restricted low fat diet on body weight and cardiovascular risk factors in healthy women. $J$ Clin Endocrinol Metab 2003, 88:1617-1623.

9. Yeomans MR: Psychological approaches to under standing satiation and satiety. Agro Food High tech 2010, 21:16-19.

10. Power ML, Schulkin J: Anticipatory physiological regulation in feeding biology: cephalic phase responses. Appetite 2008, 50:194-206.

11. Drewnowski A, Krahn DD, Demitrack MA, Nairn K, Gosnell BA: Taste responses and preferences for sweet high-fat foods: evidence for opioid involvement. Physiol Behav 1992, 51:371-379.

12. Feinman RD, Volek JS: Carbohydrate restriction as the default treatment for type 2 diabetes and metabolic syndrome. Scand Cardiovasc J 2008, 42:256-263.
13. Lankinen M, Schwab U, Gopalacharyulu PV, Seppanen-Laakso T, Yetukuri L, Sysi-Aho M, Kallio P, Suortti T, Laaksonen DE, Gylling H, Poutanen K, Kolehmainen M, Oresic M: Dietary carbohydrate modification alters serum metabolic profiles in individuals with the metabolic syndrome. Nutr Metab Cardiovasc Dis 2010, 20:249-257.

14. Atkins RC: Dr. Atkins' diet revolution; the high calorie way to stay thin forever. New York: D. McKay Co; 1972.

15. Al-Khalifa A, Mathew TC, Al-Zaid NS, Mathew E, Dashti HM: Therapeutic role of low-carbohydrate ketogenic diet in diabetes. Nutrition 2009, 25:1177-1185.

16. Dashti HM, Mathew TC, Khadada M, Al-Mousawi M, Talib H, Asfar SK, Behbahani Al, Al-Zaid NS: Beneficial effects of ketogenic diet in obese diabetic subjects. Mol Cell Biochem 2007, 302:249-256.

17. Adam-Perrot A, Clifton P, Brouns F: Low-carbohydrate diets: nutritional and physiological aspects. Obes Rev 2006, 7:49-58.

18. Sharman MJ, Kraemer WJ, Love DM, Avery NG, Gomez AL, Scheett TP, Volek JS: A ketogenic diet favorably affects serum biomarkers for cardiovascular disease in normal-weight men. J Nutr 2002, 132:1879-1885.

19. Bellisle F: Infrequently asked questions about the Mediterranean diet. Public Health Nutr 2009, 12:1644-1647.

20. Cordain L, Eaton SB, Sebastian A, Mann N, Lindeberg S, Watkins BA, O'Keefe $\mathrm{JH}$, Brand-Miller J: Origins and evolution of the Western diet: health implications for the 21st century. Am J Clin Nutr 2005, 81:341-354

21. Perez-Guisado J, Munoz-Serrano A, Alonso-Moraga A: Spanish Ketogenic Mediterranean Diet: a healthy cardiovascular diet for weight loss. Nutr J 2008, 7:30.

22. Paoli A, Cenci L, Fancelli M, Parmagnani A, Fratter A, Cucchi A, Bianco A: Ketogenic diet and phytoextracts Comparison of the efficacy of Mediterranean, zone and tisanoreica diet on some health risk factors. Agro Food Ind Hi-Tech 2010, 21:24-29.

23. Zupec-Kania B, Zupanc ML: Long-term management of the ketogenic diet: seizure monitoring, nutrition, and supplementation. Epilepsia 2008, 49(Suppl 8):23-26.

24. Gazi IF, Elisaf M: LDL-cholesterol calculation formulas in patients with or without the metabolic syndrome. Int J Cardiol 2007, 119:414-415.

25. Saunders NH, al-Zeibak S, Ryde SJ, Birks JL: The composition of weight loss in dieting obese females by electrical methods. Int $J$ Obes Relat Metab Disord 1993, 17:317-322.

26. Piccoli A, Pastori G, Codognotto M, Paoli A: Equivalence of information from single frequency v. bioimpedance spectroscopy in bodybuilders. $\mathrm{Br}$ J Nutr 2007, 97:182-192.

27. Kreider RB, Rasmussen C, Kerksick CM, Wilborn C, Taylor L, Campbell B, Magrans-Courtney T, Fogt D, Ferreira M, Li R, Galbreath M, losia M, Cooke M, Serra M, Gutierrez J, Byrd M, Kresta JY, Simbo S, Oliver J, Greenwood M: A carbohydrate-restricted diet during resistance training promotes more favorable changes in body composition and markers of health in obese women with and without insulin resistance. Phys Sportsmed 2011, 39:27-40.

28. Westerterp-Plantenga MS, Nieuwenhuizen A, Tome D, Soenen S, Westerterp KR: Dietary protein, weight loss, and weight maintenance. Annu Rev Nutr 2009, 29:21-41.

29. Paddon-Jones D, Westman E, Mattes RD, Wolfe RR, Astrup A, WesterterpPlantenga M: Protein, weight management, and satiety. Am J Clin Nutr 2008, 87:1558S-1561S

30. Soenen S, Westerterp-Plantenga MS: Proteins and satiety: implications for weight management. Curr Opin Clin Nutr Metab Care 2008, 11:747-751.

31. Veldhorst M, Smeets A, Soenen S, Hochstenbach-Waelen A, Hursel R, Diepvens K, Lejeune M, Luscombe-Marsh N, Westerterp-Plantenga M: Protein-induced satiety: effects and mechanisms of different proteins. Physiol Behav 2008, 94:300-307.

32. Vogels N, Westerterp-Plantenga MS: Successful long-term weight maintenance: a 2-year follow-up. Obesity (Silver Spring) 2007, 15:1258-1266.

33. Bravata DM, Sanders L, Huang J, Krumholz HM, Olkin I, Gardner CD, Bravata DM: Efficacy and safety of low-carbohydrate diets: a systematic review. JAMA 2003, 289:1837-1850.

34. Astrup A: The satiating power of protein-a key to obesity prevention? Am J Clin Nutr 2005, 82:1-2.

35. Soenen S, Plasqui G, Smeets AJ, Westerterp-Plantenga MS: Protein intake induced an increase in exercise stimulated fat oxidation during stable body weight. Physiol Behav 2010, 101:770-774. 
36. Soenen S, Westerterp-Plantenga MS: Changes in body fat percentage during body weight stable conditions of increased daily protein intake vs. control. Physiol Behav 2010, 101:635-638.

37. Johnstone AM, Horgan GW, Murison SD, Bremner DM, Lobley GE: Effects of a high-protein ketogenic diet on hunger, appetite, and weight loss in obese men feeding ad libitum. Am J Clin Nutr 2008, 87:44-55.

38. McClernon FJ, Yancy WS Jr, Eberstein JA, Atkins RC, Westman EC: The effects of a low-carbohydrate ketogenic diet and a low-fat diet on mood, hunger, and other self-reported symptoms. Obesity (Silver Spring) 2007, 15:182-187.

39. Cabeza De Vaca S, Holiman S, Carr KD: A search for the metabolic signal that sensitizes lateral hypothalamic self-stimulation in food-restricted rats. Physiol Behav 1998, 64:251-260.

40. Cahill GF Jr: Fuel metabolism in starvation. Annu Rev Nutr 2006, 26:1-22.

41. Sato K, Kashiwaya Y, Keon CA, Tsuchiya N, King MT, Radda GK, Chance B, Clarke K, Veech RL: Insulin, ketone bodies, and mitochondrial energy transduction. FASEB J 1995, 9:651-658.

42. Robinson AM, Williamson DH: Physiological roles of ketone bodies as substrates and signals in mammalian tissues. Physiol Rev 1980, 60:143-187.

43. Veldhorst MA, Westerterp-Plantenga MS, Westerterp KR: Gluconeogenesis and energy expenditure after a high-protein, carbohydrate-free diet. Am J Clin Nutr 2009, 90:519-526.

44. Vazquez JA, Kazi U: Lipolysis and gluconeogenesis from glycerol during weight reduction with very-low-calorie diets. Metabolism 1994, 43:1293-1299.

45. Langfort J, Pilis W, Zarzeczny R, Nazar K, Kaciuba-Uscillko H: Effect of lowcarbohydrate-ketogenic diet on metabolic and hormonal responses to graded exercise in men. J Physiol Pharmacol 1996, 47:361-371.

46. Feinman RD, Fine EJ: Nonequilibrium thermodynamics and energy efficiency in weight loss diets. Theor Biol Med Model 2007, 4:27.

47. Feinman RD, Fine EJ: Whatever happened to the second law of thermodynamics? Am J Clin Nutr 2004, 80:1445-6, author reply 1446.

48. Feinman RD, Fine EJ: "A calorie is a calorie" violates the second law of thermodynamics. Nutr J 2004, 3:9.

49. Feinman RD, Fine EJ: Thermodynamics and metabolic advantage of weight loss diets. Metab Syndr Relat Disord 2003, 1:209-219.

50. Fine EJ, Feinman RD: Thermodynamics of weight loss diets. Nutr Metab (Lond) 2004, 1:15.

51. Jequier E: Pathways to obesity. Int J Obes Relat Metab Disord 2002, 26(Suppl 2):S12-17.

52. Lofgren I, Zern T, Herron K, West K, Sharman MJ, Volek JS, Shachter NS, Koo SI, Fernandez ML: Weight loss associated with reduced intake of carbohydrate reduces the atherogenicity of LDL in premenopausal women. Metabolism 2005, 54:1133-1141.

53. Volek JS, Sharman MJ, Forsythe CE: Modification of lipoproteins by very low-carbohydrate diets. J Nutr 2005, 135:1339-1342.

54. Volek JS, Sharman MJ, Gomez AL, Scheett TP, Kraemer WJ: An isoenergetic very low carbohydrate diet improves serum HDL cholesterol and triacylglycerol concentrations, the total cholesterol to HDL cholesterol ratio and postprandial pipemic responses compared with a low fat diet in normal weight, normolipidemic women. J Nutr 2003, 133:2756-2761.

55. Austin MA, King MC, Vranizan KM, Krauss RM: Atherogenic lipoprotein phenotype. A proposed genetic marker for coronary heart disease risk. Circulation 1990, 82:495-506.

56. Siliprandi N, Tettamanti G: Biochimica medica: strutturale, metabolica e funzionale. Padova: Piccin; 2005.

57. Krebs HA: The regulation of the release of ketone bodies by the liver. Adv Enzyme Regul 1966, 4:339-354.

58. Samuel VT: Fructose induced lipogenesis: from sugar to fat to insulin resistance. Trends Endocrinol Metab 2011, 22:60-65.

59. Madero M, Arriaga JC, Jalal D, Rivard C, McFann K, Perez-Mendez O, Vazquez A, Ruiz A, Lanaspa MA, Jimenez CR, Johnson RJ, Lozada LG: The effect of two energy-restricted diets, a low-fructose diet versus a moderate natural fructose diet, on weight loss and metabolic syndrome parameters: a randomized controlled trial. Metabolism; 2011.

60. Klein P, Janousek J, Barber A, Weissberger R: Ketogenic diet treatment in adults with refractory epilepsy. Epilepsy Behav 2010, 19:575-579.

61. Mosek A, Natour H, Neufeld MY, Shiff Y, Vaisman N: Ketogenic diet treatment in adults with refractory epilepsy: a prospective pilot study. Seizure 2009, 18:30-33.
62. Jia Y, Hwang SY, House JD, Ogborn MR, Weiler HA, O K, Aukema HM: Longterm high intake of whole proteins results in renal damage in pigs. $J$ Nutr 2010, 140:1646-1652.

63. Wakefield AP, House JD, Ogborn MR, Weiler HA, Aukema HM: A diet with $35 \%$ of energy from protein leads to kidney damage in female SpragueDawley rats. Br J Nutr 2011, , 106: 656-63.

64. Skov AR, Haulrik N, Toubro S, Molgaard C, Astrup A: Effect of protein intake on bone mineralization during weight loss: a 6-month trial. Obes Res 2002, 10:432-438.

65. Martin WF, Armstrong LE, Rodriguez NR: Dietary protein intake and renal function. Nutr Metab (Lond) 2005, 2:25.

66. Welle $\mathrm{S}$, Nair KS: Relationship of resting metabolic rate to body composition and protein turnover. Am J Physiol 1990, 258:E990-998.

67. Westerterp-Plantenga MS: How are normal, high- or low-protein diets defined? Br J Nutr 2007, 97:217-218

68. Poplawski MM, Mastaitis JW, Isoda F, Grosjean F, Zheng F, Mobbs CV: Reversal of diabetic nephropathy by a ketogenic diet. PLoS One 2011, 6 e18604.

69. Lugasi A, Blazovics A, Hagymasi K, Kocsis I, Kery A: Antioxidant effect of squeezed juice from black radish (Raphanus sativus L. var niger) in alimentary hyperlipidaemia in rats. Phytother Res 2005, 19:587-591.

70. Lou Z, Wang H, Li J, Chen S, Zhu S, Ma C, Wang Z: Antioxidant activity and chemical composition of the fractions from burdock leaves. J Food Sci 2010, 75:C413-419.

71. Di Silverio F, D'Eramo G, Lubrano C, Flammia GP, Sciarra A, Palma E, Caponera M, Sciarra F: Evidence that Serenoa repens extract displays an antiestrogenic activity in prostatic tissue of benign prostatic hypertrophy patients. Eur Urol 1992, 21:309-314.

72. Barrett ML, Udani JK: A proprietary alpha-amylase inhibitor from white bean (Phaseolus vulgaris): a review of clinical studies on weight loss and glycemic control. Nutr J 2011, 10:24.

73. Celleno L, Tolaini MV, D'Amore A, Perricone NV, Preuss HG: A Dietary supplement containing standardized Phaseolus vulgaris extract influences body composition of overweight men and women. Int J Med Sci 2007, 4:45-52.

74. Mimica-Dukic N, Simin N, Cvejic J, Jovin E, Orcic D, Bozin B: Phenolic compounds in field horsetail (Equisetum arvense L.) as natural antioxidants. Molecules 2008, 13:1455-1464.

75. Safiyeh S, Fathallah FB, Vahid N, Hossine N, Habib SS: Antidiabetic effect of Equisetum arvense L. (Equisetaceae) in streptozotocin-induced diabetes in male rats. Pak J Biol Sci 2007, 10:1661-1666.

76. Clare BA, Conroy RS, Spelman K: The diuretic effect in human subjects of an extract of Taraxacum officinale folium over a single day. J Altern Complement Med 2009, 15:929-934.

77. Pieralisi G, Ripari P, Vecchiet L: Effects of a standardized ginseng extract combined with dimethylaminoethanol bitartrate, vitamins, minerals, and trace elements on physical performance during exercise. Clin Ther 1991, 13:373-382.

78. Piato AL, Detanico BC, Linck VM, Herrmann AP, Nunes DS, Elisabetsky E: Anti-stress effects of the "tonic"Ptychopetalum olacoides (Marapuama) in mice. Phytomedicine 2010, 17:248-253.

79. Lima WP, Carnevali LC Jr, Eder R, Costa Rosa LF, Bacchi EM, Seelaender MC: Lipid metabolism in trained rats: effect of guarana (Paullinia cupana Mart.) supplementation. Clin Nutr 2005, 24:1019-1028.

\section{doi:10.1186/1475-2891-10-112}

Cite this article as: Paoli et al:: Effect of Ketogenic Mediterranean diet with phytoextracts and low carbohydrates/high-protein meals on weight, cardiovascular risk factors, body composition and diet compliance in Italian council employees. Nutrition Journal 2011 10:112. 